\title{
IMPACT OF THE COVID-19 PANDEMIC ON YOUTH UNEMPLOYMENT IN THE EUROPEAN UNION
}

\author{
Maya Lambovska ${ }^{1, a,{ }^{*}}$ Boguslawa Sardinha ${ }^{2, b}$ and Jaroslav Belas, Jr. ${ }^{3, c}$ \\ ${ }^{1}$ University of National and World Economy, Sofia, Bulgaria \\ ${ }^{2}$ School of Business Management, Polytechnic Institute of Setúbal, Portugal \\ ${ }^{3}$ Alexander Dubcek University in Trencin, Studentska 2, 91150 Trencin, Slovakia \\ am.lambovska@abv.bg, bboguslawa.sardinha@esce.ips.pt, cjaroslav.belas@tnuni.student.sk \\ "Corresponding author
}

Cite as: Lambovska, M., Sardinha, B., Belas, J. (2021). Impact of covid-19 pandemic on the Youth unemployment in the European Union, Ekonomicko-manazerske spektrum, 15(1), 55-63.

Available at: dx.doi.org/10.26552/ems.2021.1.55-63

Received: 11 December 2020; Received in revised form: 4 April 2021; Accepted: 17 April 2021; Available online: 21 April 2021

\begin{abstract}
Youth unemployment is a problem in each member country of the European Union (EU). The EU seeks to alleviate this problem by implementing various programs to support young people in finding and keeping a job, thus contributing to economic growth. In 2020, the world was hit by the COVID-19 pandemic. The countries have introduced many strict measures to prevent its spread, but they have caused a significant increase in unemployment, including among young people, and thus harmed economic growth. In this paper, we analyze the unemployment of people under the age of twenty-five in the EU. We also point out how unemployment rates have increased in individual countries. This problem concerns not only countries where the youth unemployment rate had been high already, such as Greece, Spain, and Italy, but also countries with previously lower rates, for example, the Czech Republic, Netherland, Poland, and Slovenia. In the latter group of countries, the youth unemployment rate has doubled in some cases due to anti-pandemic measures. We found that the most affected countries in this regard are the aforementioned Czech Republic, where the unemployment rate at the end of 2020 rose to 2.19 times above the level at the end of 2019, and Estonia, where year-over-year youth unemployment rose by a factor of 2.5. However, unfavorable developments occurred also in Lithuania, Latvia, and Ireland. According to our results, in 2020, youth unemployment increased the least in Hungary, Italy, and Belgium. In general, however, as the situation is now much more urgent, measures to alleviate this problem need to be put in place in each country to help young people find employment and, thus, stimulate economic growth.
\end{abstract}

Keywords: youth unemployment; COVID-19; anti-pandemic measures; European Union.

JEL Classification: J21; J64

\section{Introduction}

Employment has an irreplaceable place in the life of everyone, even a young person. Work gives people material security, a sense of self-realization, and utility in society. Young graduates, looking for their first job after graduation, are among the most vulnerable groups in the labor market. Summer, the period when most young people finish their studies, is usually 
connected with an increased inflow of newly unemployed and thus an overall increase in the number of jobseekers. However, a problem arises when some young people who do not work, do not study or participate in training programs, wish to find employment, but are prevented from doing so due to a lack of job opportunities. In such cases, it is essential to lend them a helping hand, ensuring their access to employment opportunities and thus reducing youth unemployment. Many countries in the European Union (EU) have long been trying to alleviate the problem. The European Union puts great importance to addressing the issue and provides solutions through specific programs targeted at young people, the main aim of which is to help them enter the labor market and increase their employment rate. Assistance from the European Union and its programs, interventions, and measures is very much needed and necessary in this case. The initiatives and programs adopted to help young people have helped countries reduce unemployment and support young people in finding employment and remaining in the labor market.

The youth unemployment rate varies from one EU country to another, with the unemployment rate at the end of 2019 ranging from the lowest value of $4.7 \%$ in the Czech Republic to the highest value of $32.4 \%$ in Greece. In 2020, however, the world was hit by the COVID-19 pandemic. Several countries have introduced anti-pandemic measures to varying degrees to prevent the spread of the virus. These measures often interfere with, limit, or stop business operations. This, of course, in many cases results in redundancies or even bankruptcy of companies, which in turn significantly increases unemployment. This situation affects all sections of the population, including young people. In this context, the main aim of this paper is to analyze the extent to which the COVID-19 pandemic, or rather measures to prevent its spread, have caused an increase in the unemployment rate of young people under the age of twenty-five in the individual EU countries, but also across the EU. The current state of youth unemployment in the EU is described in the paper. We then analyze which countries are the most affected by the pandemic in terms of youth unemployment rates.

The rest of the paper is organized into five sections: literature review, methodology, results, discussion, and conclusion. The literature review section mentions several studies that focus on the issue of youth unemployment in recent years. In the methodology section, we present the development of the youth unemployment rate in the EU and describe the further processing of the data reported for the individual EU countries. The results section shows the EU countries with the highest youth unemployment rates at the end of 2020, affected by the COVID-19 pandemic. In the discussion section, we comment on what tools should be used to alleviate the problem of youth unemployment and thus suggest a possible further direction of this study. The last section concludes the paper.

\section{Literature review}

Several authors deal with youth unemployment in their studies. In this review, we focus our attention mainly on the studies from 2020 and 2021 given the situation with the COVID-19 pandemic.

In particular, we would like to note the publications of several authors.

In their study, Lyshol et al. (2021) focused on analysis of whether the duration of unemployment of young people has a negative impact on the probability of their employment. The authors explore how duration dependence varies with an individual's labor market experience. The results of the study show that duration dependence differs between new entrants to the labor market and experienced workers. The authors also found that duration 
dependence is stronger for experienced workers compared with new entrants into the labor force.

Wesseling's study (2021) evaluates the impact of participation in an intervention program for young unemployed people in the Netherlands. Young unemployed people aged eighteen to twenty-seven who participated in the employment support program were surveyed within the twelve months following their participation in the program. The author found that most of them were hired during this period. Simultaneously, the study seeks to identify indicators that increase and decrease job success of these young participants in the program.

An evaluation of the program for young unemployed is also provided by Svabova and Kramarova (2021). Their study is focused on young unemployed people in Slovakia who, after graduation, participate in the Graduate Practice Program. These young people were monitored for two years after the end of this program, and the authors of the study examined the impact of participating in the program on the course of their employment. In studies by Svabova et al. (2019a) and Svabova et al. (2019b), the authors also investigated similar issues related to the evaluation of Graduate Practice effects in Slovakia on the youth employment.

In their study, Scandurra et al. (2021) explored in-depth young unemployed people as well as the territorial distribution of young people's opportunities at the regional level in the EU. They also examined the extent to which employment conditions, skills supply, and technological resources explain interregional differences in youth labor market integration.

Butkus et al. (2020), in their study, examined the relationship between the impact of economic growth and unemployment, focusing on the sensitivity of the unemployment rate to age, gender, and educational level. The authors found that the coefficients specific to men and young people rise significantly in periods of negative output changes. They also found that the level of education is an important factor explaining the heterogeneity of the unemployment response to a change in output.

In Maguire's study (2020), the author explored the role of the UK's post-sixteen education and training system in supporting the young unemployed. The author critically evaluates the programs for post-sixteen young people in the form of full-time educational opportunities. Their aim should be extending qualification attainment and delaying labor market entry. The author emphasizes that the UK lacks the opportunity structures and support mechanisms to enable most young people, and particularly those from disadvantaged groups, to secure and sustain qualitative jobs and training.

Churchill's study (2020) focuses on the impact of the COVID-19 pandemic on the unemployment of young people, who are supposed to be the least vulnerable group in this pandemic. The study focused on young people in Australia. The author found that young people have been more significantly impacted by COVID-19 compared to older Australians and that the strongest impacts are on young women over the age of twenty.

Other authors who have addressed the issue of the young unemployed in their studies are Alfonsi et al. (2020), Assmann et al. (2020), Bennett and Ouazad (2020), Berlin et al. (2020), Bradley and Crouchley (2020), Frias et al. (2020), Krasnopjorovs (2020), Liotti (2020), Mussida and Sciulli (2020), Pastore et al. (2020), Pastore and Pompili (2020), Scharfenort (2020), Habanabakize et al. (2019). More generally, the impact of the COVID-19 pandemic on unemployment is analyzed in the studies of Achdut and Refaeli (2020), Autin et al. (2020), Barcakova and Janas (2019), Kantova and Arltova (2020), Mangan (2020), McGann et al. (2020), Parola (2020), Sachs (2020), Sprague et al. (2020). 


\section{Methodology}

The data used in this study were taken from the Eurostat database. The youth unemployment rate in the countries of the European Union is visualized in Figure 1.

Figure 1: Youth unemployment rates, EU-27 and EA-19, seasonally adjusted, January 2005 - December 2020

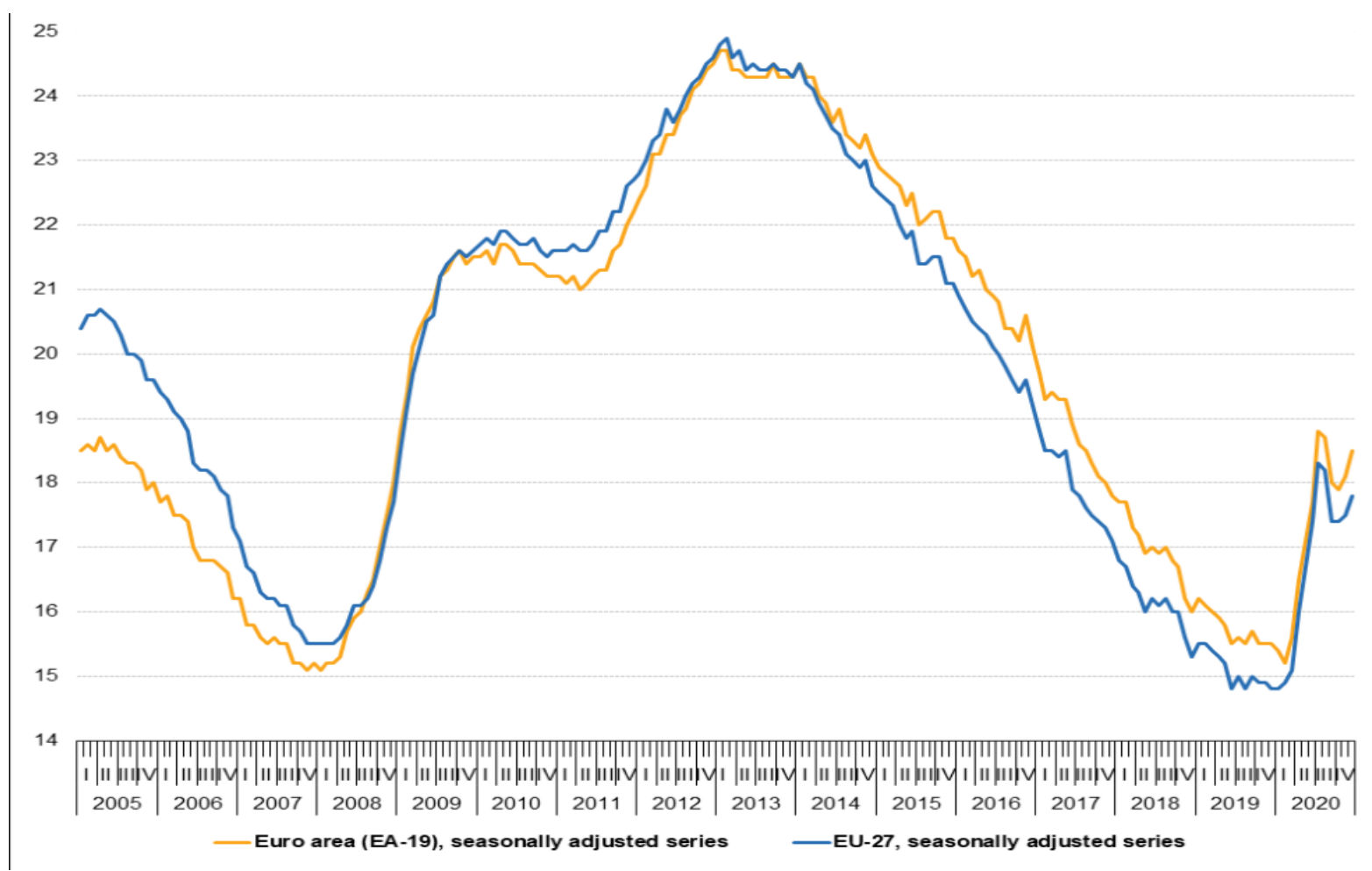

Source: database Eurostat (https://ec.europa.eu, 2021)

In addition, we took a closer look at the development of the rate and number of unemployed in individual EU countries, using the Eurostat database. which we process using the data in this database. We used the data from the last month of 2019 (as a benchmark for comparison and evaluation of the impact of the pandemic on the youth unemployment rate) and subsequently from the last four months of 2020 when the COVID-19 pandemic had a very large impact on the unemployment rate in all EU countries. Specifically, we studied the five EU countries that had the highest unemployment rates during these months.

We also analyzed the percentage increase in the unemployment rate and the number of youth unemployed, and, as a result, identified which countries had the largest increase in these indicators during the pandemic.

Additionally, we identified those countries where the situation is more favorable, i.e. where the pandemic has not significantly contributed to the increase in the number of unemployed young people.

\section{Results}

Using data on the number of unemployed young people and their unemployment rates, here we analyze in more detail the acuteness of this problem in individual EU countries.

Figure 2 shows the unemployment rates among young people under the age of twenty-five for the last month of 2019 compared to the last four months of 2020. The latter year was when the pandemic hit hard and the measures against it caused an increase in unemployment across 
all countries and demographics, including young people. For each period, we show the five EU countries with the highest youth unemployment rates, as well as the youth unemployment rate for the whole EU (the orange line). Some countries (Estonia, Greece, Hungary, Romania, Norway, and Switzerland) do not have complete data for some months, especially for December 2020. In each period, countries are ranked according to the unemployment rate, expressed as a percentage. As shown in Figure 2, the highest youth unemployment rate at the end of 2019 was in Greece (32.4\%), followed by Spain (30.3\%), Italy (28.4\%), Sweden (20.4\%), and France (20.2\%). Although there was still no COVID-19 pandemic at the end of 2019, these rates were already very high. The EU unemployment rate for young people under the age of twenty-five was $14.8 \%$. In comparison, the lowest rates were found in the Czech Republic (4.7\%), Germany $(5.6 \%)$, and the Netherlands $(6.7 \%)$.

Figure 2: Countries with the highest youth unemployment rates in the EU

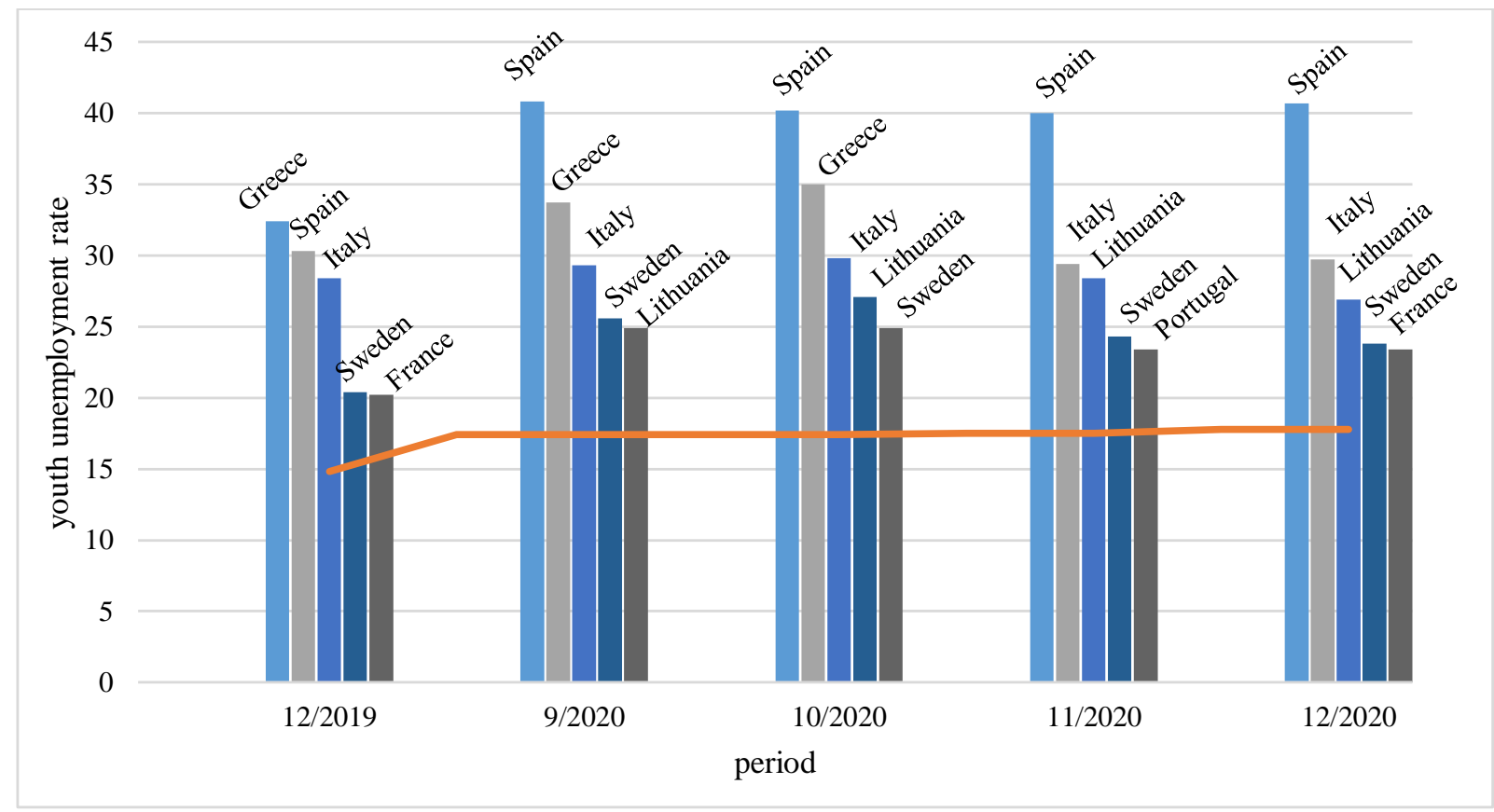

Source: own elaboration based on the data from database Eurostat (https://ec.europa.eu, 2021)

Also shown in Figure 2 are the last four months of 2020 in which unemployment rates in all EU countries were already affected by anti-pandemic measures. Individual countries introduced their own measures with varying degrees of strictness, and their impact may therefore have likewise varied. Figure 2 clearly shows a hike in the unemployment rate in all countries, although restrictions have been introduced in each EU country, which has led to a higher number of unemployed people, including in the youth segment.

We can see that Greece, where the youth unemployment rate was the highest before the pandemic, ranked second worst by the end of September 2020, with the already high youth unemployment rate rising further to 35\%. In November and December of 2020, data from Greece was not recorded. For this reason, Greece is missing from these two months' ranking. But we assume that the unemployment has remained at the same level or has climbed even higher. The situation was even worse in Spain, where youth unemployment reached a record high of over $40 \%$, an increase of more than $10 \%$ from the previous year. In Spain, almost 600,000 young people were unemployed at the end of 2020, with the peak in September 2020 reaching 601,000. In Italy, there was likewise a slight increase in the youth unemployment rate, 
to almost $30 \%$, or next to 400,000 unemployed people. In Sweden, which was one of the "top 5 " countries by youth unemployment rate at the end of 2019, the situation worsened in 2020, with the youth unemployment rate having risen from $20.4 \%$ to $23.8 \%-25.6 \%$, which translates to 20,000 more unemployed young people than in the year before the pandemic. The situation also worsened in Lithuania, for example, where the youth unemployment rate almost doubled, rising from $14.9 \%$ in 2019 to $24.9 \%-28.4 \%$ in the pandemic year.

The development of youth unemployment in the most affected countries, in terms of the largest increase in the number and rate of youth unemployment in 2020 compared to the end of 2019, is shown in Figure 3. The numbers for the earliest (December 2019) and latest recorded period (December 2020) listed in Figure 3, are the numbers of young unemployed people in thousands.

Figure 3: Countries with the highest impact of COVID-19 pandemic on the youth unemployment rates in the EU

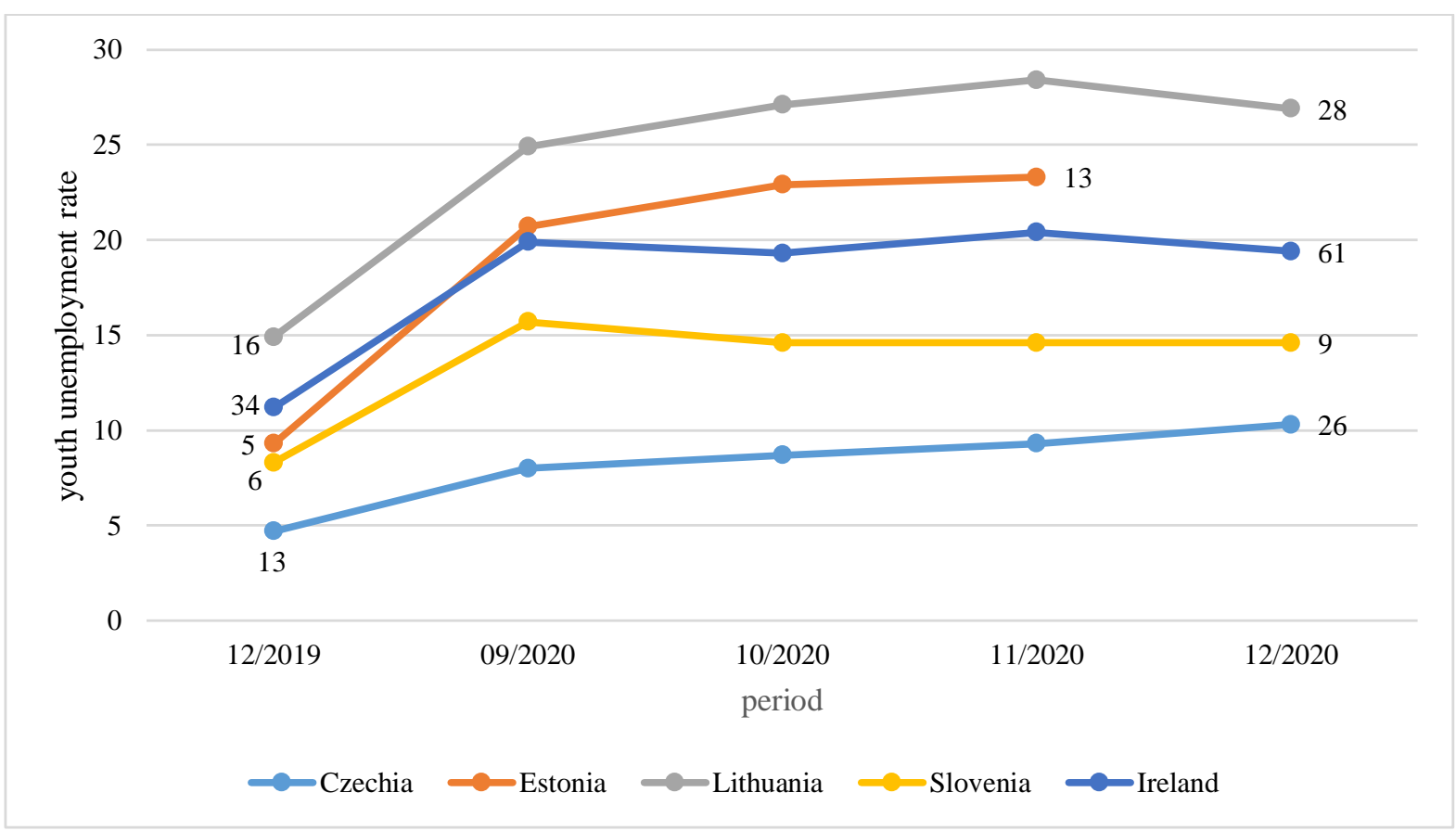

Source: own elaboration based on the data from database Eurostat (https://ec.europa.eu, 2021)

The situation in the Czech Republic or the Netherlands, countries with the lowest youth unemployment rates in 2019, deteriorated significantly as well. In the Netherlands, there was a significant increase in youth unemployment, from $6.7 \%$ at the end of 2019 to $9.4 \%-10.7 \%$ in 2020. The number of unemployed young people increased by $50 \%$, from 101,000 to more than 150,000. In the Czech Republic, the youth unemployment rate rose from 4.7\%, EU's lowest level at the end of 2019 , to $10.3 \%$ at the end of 2020 , the number of unemployed young people doubling from 13,000 to 26,000 . This is the worst relative development on record, topped only by Estonia's youth unemployment rate increase of 2.5 times compared to 2019 when the original number of unemployed young people rose from 5,000 to 13,000.

The evolution of youth unemployment in countries with the lowest increase in their number in the year 2020 is shown in Figure 4. 
Figure 4: Countries with the lowest impact of COVID-19 pandemic on the youth unemployment rates in the EU

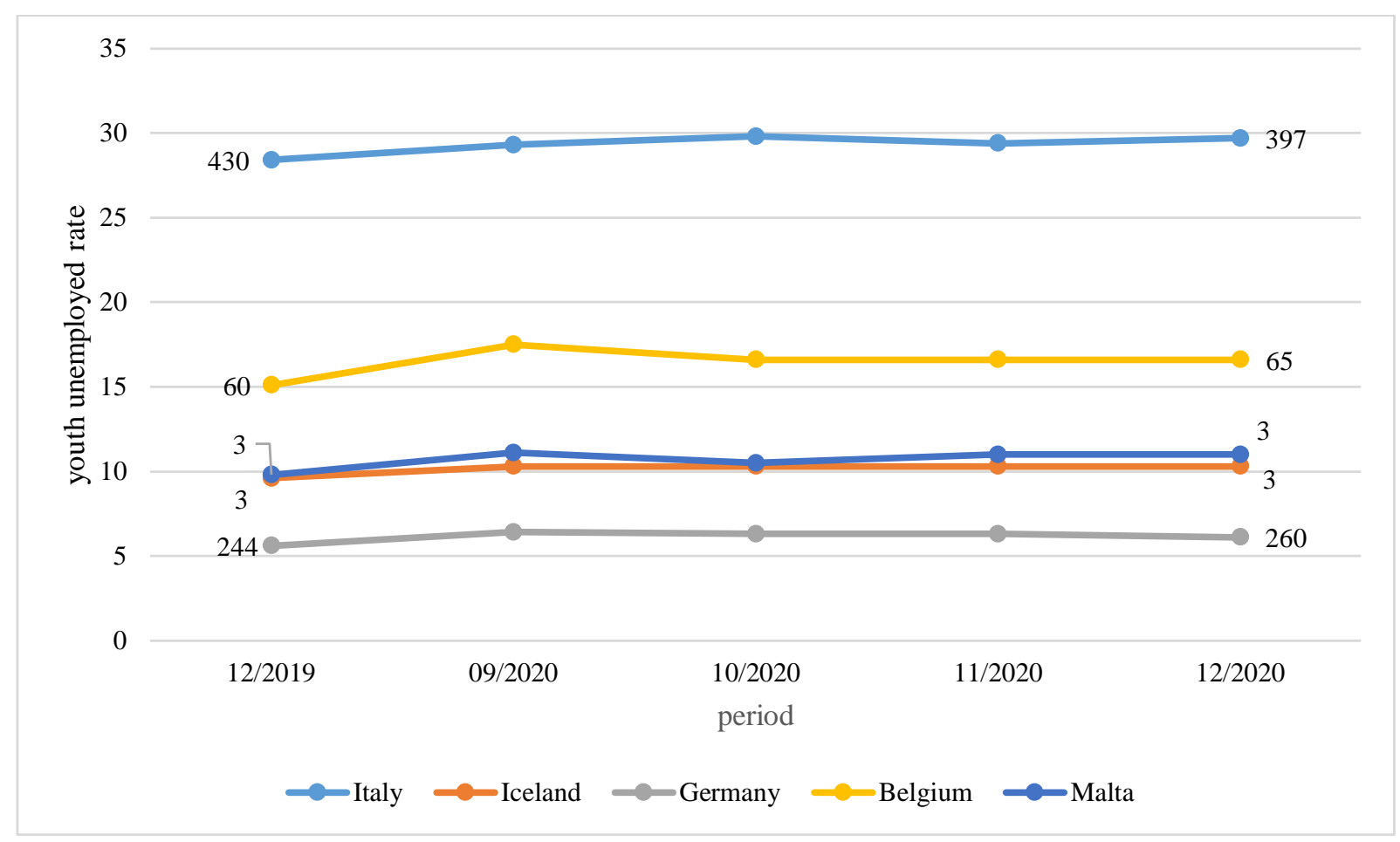

Source: own elaboration based on the data from database Eurostat (https://ec.europa.eu, 2021)

As in the previous figure, the numbers in the earliest (December 2019) and latest recorded period (December 2020) are the numbers of young unemployed people in thousands.

\section{Discussion}

In the results section, we presented the main trends in youth unemployment in the EU countries, focusing mainly on 2020 . We examined the development of the rate and number of young unemployed people compared to the end of 2019.

The results showed that the highest youth unemployment rates were found in Greece, Italy, Spain, Sweden, and Lithuania for the period 09.2020 - 09.2021, with France and Portugal joining in 2020. Youth unemployment is a long-term problem in countries like Greece and Italy where its rate exceeded $30 \%$ even in 2019, in contrast to countries at the opposite end of the spectrum, such as the Czech Republic, Germany, and the Netherlands. In 2020, the situation changed in some countries even dramatically due to the COVID-19 pandemic. An example is the Czech Republic, where the original EU's lowest youth unemployment rate doubled year over year by the end of 2020. Similar unfavorable developments are observed in the Netherlands and Estonia, where the number of unemployed young people increased by a factor of 2.5. However, there are countries where the development of youth unemployment has not been so dramatic, such as Germany, Iceland, Italy, Belgium, and Malta. In these countries, the number of unemployed young people increased in 2020 compared to the end of 2019, but to a much lesser extent.

The results obtained in this study can be further analyzed and used in subsequent investigation of the more specific causes behind the increase of youth unemployment, and in designing tools to address this unfavorable situation. We expect the EU member states to implement various active and instruments, labor-market policies, programs, and instruments, 
including those related to corporate social responsibility (Matev et al., 2009), to support youth employment and mitigate the aforementioned adverse effects of the 2020 pandemic.

\section{Conclusion}

The COVID-19 pandemic has had an impact on the lives of citizens across the EU and on the economic growth of the member states in general. The governments introduced various degrees of anti-pandemic measures to prevent the spread of the virus, which restricted or stopped operation of certain facilities, businesses, or services. This has had a significant impact on unemployment, including in the segment of young people, who in this case are a vulnerable group, often looking for their first job.

The paper analyzed which EU countries recorded the most significant increase in the rate and number of unemployed youth under twenty-five years of age in 2020 compared to the situation at the end of 2019. The EU countries with the highest youth unemployment rates were also listed, which is a long-term problem for some of them. Additionally, we presented the countries where the development of youth unemployment rate was least severe in terms of the smallest increase in the number of unemployed young people.

In conclusion, it is clear that once the most critical phase of the pandemic is partially alleviated, part of the EU and individual member countries will need to stimulate economic growth, also focusing on the segment of potential job-seekers and implementing employment support programs. Many such programs have been running for some time. They are beneficial for young people, but such support may need to be increased and adapted to the current situation.

\section{References}

Achdut, N., \& Refaeli, T. (2020). Unemployment and psychological distress among young people during the covid-19 pandemic: Psychological resources and risk factors. International Journal of Environmental Research and Public Health, 17(19), 7163.

Alfonsi, L., Bandiera, O., Bassi, V., Burgess, R., Rasul, I., Sulaiman, M., \& Vitali, A. (2020). Tackling youth unemployment: Evidence from a labor market experiment in uganda. Econometrica, 88(6), 2369-2414.

Assmann, M.-L., Tolgensbakk, I., Vedeler, J. S., \& Bøhler, K. K. (2020). Public employment services: Building social resilience in youth? Social Policy \& Administration, forthcomming article.

Autin, K. L., Blustein, D. L., Ali, S. R., \& Garriott, P. O. (2020). Career development impacts of COVID-19: Practice and policy recommendations. Journal of Career Development, 47(5), 487-494.

Barcakova, M., \& Janas, K. (2019). Youth unemployment in Slovakia and in Slovenia. Izzivi Prihodnosti/ Challenges of the Future, 4(2), 98-105.

Bennett, P., \& Ouazad, A. (2020). Job displacement, unemployment, and crime: Evidence from Danish microdata and reforms. Journal of the European Economic Association, 18(5), 2182-2220.

Berlin, M., Kääriälä, A., Lausten, M., Andersson, G., \& Brännström, L. (2020). Long-term NEET among young adults with experience of out-of-home care: A comparative study of three Nordic countries. International Journal of Social Welfare, forthcoming article.

Bradley, A. P. (1997). The use of the area under the ROC curve in the evaluation of machine learning algorithms. Pattern Recognition, 30(7), 1145-1159.

Bradley, S., \& Crouchley, R. (2020). The effects of test scores and truancy on youth unemployment and inactivity: A simultaneous equations approach. Empirical Economics, 59(4), 1799-1831.

Butkus, M., Matuzeviciute, K., Rupliene, D., \& Seputiene, J. (2020). Does unemployment responsiveness to output change depend on age, gender, education, and the phase of the business cycle? Economies, 8(4), 98.

Churchill, B. (2020). COVID-19 and the immediate impact on young people and employment in Australia: A gendered analysis. Gender, Work \& Organization, forthcoming article (Early Access: Oct 2020).

Frias, M., Alcoforado, L., \& Cordeiro, A. R. (2020). The neet youth case: New trajectories, new challenges. Revista Praxis Educacional, 16(42), 186-216. 
Habanabakize, T., Meyer, D. F., \& Oláh, J. (2019). The impact of productivity, investment and real wages on employment absorption rate in South Africa. Social Sciences, 8(12), 330, 1-15.

Kantova, M., \& Arltova, M. (2020). Emerging from crisis: Sweden's active labour market policy and vulnerable groups. The Economic and Labour Relations Review, 31(4), 543-564.

Krasnopjorovs, O. (2020). Have the Baltic countries run out of labour reserves? TalTech Journal of European Studies, 10(3), 45-66.

Liotti, G. (2020). Labour market flexibility, economic crisis and youth unemployment in Italy. Structural Change and Economic Dynamics, 54, 150-162.

Lyshol, A. F., Nenov, P. T., \& Wevelstad, T. (2021). Duration dependence and labor market experience. Labour, $35(1), 105-134$.

Maguire, S. (2020). One step forward and two steps back? The UK's policy response to youth unemployment. Journal of Education and Work, 33(7-8), 515-521.

Mangan, D. (2020). Covid-19 and labour law in the United Kingdom. European Labour Law Journal, 11(3), 332346.

Matev, D., Gospodinova, Z., Peev, G., \& Yordanov, K. (2009). The corporate social responsibility in Bulgaria. Revue Management et Avenir, 23(3), 47-60.

McGann, M., Murphy, M. P., \& Whelan, N. (2020). Workfare redux? Pandemic unemployment, labour activation and the lessons of post-crisis welfare reform in Ireland. International Journal of Sociology and Social Policy, 40(9/10), 963-978.

Mussida, C., \& Sciulli, D. (2020). Does the first job affect current youth working status in Bangladesh? International Journal of Manpower, ahead-of-print (ahead-of-print).

Parola, A. (2020). Novel coronavirus outbreak and career development: A narrative approach into the meaning for Italian university graduates. Frontiers in Psychology, 11, 2255.

Pastore, F., \& Pompili, M. (2020). Assessing the impact of off-the-job and on-the-job training on employment outcomes: A counterfactual evaluation of the PIPOL program. Evaluation Review, 44(2-3), 145-184.

Pastore, F., Quintano, C., \& Rocca, A. (2020). Stuck at a crossroads? The duration of the Italian school-to-work transition. International Journal of Manpower, forthcomming article.

Sachs, T. (2020). Covid-19 and labour law in France. European Labour Law Journal, 11(3), 286-291.

Scandurra, R., Cefalo, R., \& Kazepov, Y. (2021). Drivers of youth labour market integration across European regions. Social Indicators Research, forthcomming article.

Scharfenort, N. (2020). Generating jobs for youth GCC nationals? - Tourism development, demographic change, and labour market situation in GCC countries. Zeitschrift Für Tourismuswissenschaft, 12(2), 274-298.

Sprague, A., Raub, A., \& Heymann, J. (2020). Providing a foundation for decent work and adequate income during health and economic crises: Constitutional approaches in 193 countries. International Journal of Sociology and Social Policy, 40(9/10), 1087-1105.

Svabova, L., Durica, M., Kramarova, K., Valaskova, K., \& Janoskova, K. (2019). Employability and sustainability of young graduates in the slovak labour market: Counterfactual approach. Sustainability, 11(6), 16.

Svabova, L., \& Kramarova, K. (2021). An analysis of participation factors and effects of the active labour market measure Graduate practice in Slovakia - Counterfactual approach. Evaluation and Program Planning, forthcoming article,

Svabova, L., Durica, M., \& Kliestik, T. (2019). Modelling the costs of unemployment for young graduates in slovakia: A counterfactual approach. Politická Ekonomie, 67(5), 552-566.

Wesseling, W. I. E. (2021). Towards a more all-inclusive evaluation of interventions for unemployed youth: A longitudinal investigation of participant, programme, relational and contextual factors. Social Policy \& Administration, forthcoming article. 